\title{
PASSIVE ENERGY REDUCTION TECHNOLOGIES IN ENVIRONMENTAL ENGINEERING
}

\section{TECHNOLOGIE PASYWNEGO OGRANICZANIA ZUŻYCIA ENERGII W INŻYNIERII ŚRODOWISKA}

DOI: $10.30540 /$ sae-2018-016

\begin{abstract}
The paper presents a review of passive techniques used in environmental engineering and construction, aimed at reducing energy consumption for heating or cooling purposes. These are: green facades, cooling coatings, thermopaints, heater screens, shutters and other solutions. Their disadvantages, advantages and working methods were discussed. The heat gain calculations for the exemplary building whose baffles were painted with pigmented pigment with varying degrees of dilution resulted in a facade of varying color intensity. It has been found that by applying bright colors, nearly 30 percent of energy consumption for cooling purposes for heat gains through opaque seams compared to dark colors has been reduced.
\end{abstract}

Keywords: passive technologies, cooling, cooling coatings, green facades

\section{Streszcze n i e}

W pracy przedstawiono przegląd technik pasywnych stosowanych w inżynierii środowiska i budownictwie, których zadaniem jest ograniczenie zużycia energii na cele grzewcze lub chłodnicze. Sa to: zielone fasady, powłoki chłodzace, termofarby, ekrany zagrzejnikowe, żaluzje oraz inne rozwiąania. Przedyskutowano ich wady, zalety oraz sposób pracy. Przedstawiono również obliczenia zysków ciepła dla przykładowego budynku, którego przegrody zostały pomalowane farba zabarwiona pigmentem o różnym stopniu rozcieńczenia, czego wynikiem jest fasada o różnej intensywności koloru. Stwierdzono, że przez zastosowanie jasnego koloru doszło do obniżenia o blisko 30 procent zużycia energii na cele chłodnicze dla zysków ciepła przez przegrody nieprzezroczyste w porównaniu z ciemna barwa.

Słowa kluczowe: technologie pasywne, chłodzenie, powłoki chłodzące, zielone fasady

\section{INTRODUCTION}

One of the objectives of the discipline of science as Environmental Engineering is to find new ways of saving energy, which as a result of exploitation of energy resources becomes increasingly difficult to access and their combustion causes negative effects on the environment. Their limitation requires radical action. This is primarily the case for the largest nonrenewable energy consumer, which is construction, industry and transport. One way to reduce fuel consumption is to replace them with others, including renewables. The search for new resources from renewable sources focuses on the use of solar, wind, hydro, geothermal and biofuels.

\section{WPROWADZENIE}

Jednym $\mathrm{z}$ celów inżynierii środowiska jest poszukiwanie nowych metod oszczędzania energii, która na skutek eksploatowania surowców energetycznych staje się coraz trudniej dostępna, a ich spalanie powoduje negatywne skutki dla środowiska. Ich ograniczenie wymaga zastosowania radykalnych działań Dotyczy to przede wszystkim największych konsumentów energii nieodnawialnej, którymi są budownictwo, przemysł i transport. Jednym ze sposobów ograniczenia zużycia paliw jest ich zastąpienie innymi, w tym odnawialnymi. Poszukiwania nowych zasobów w obszarze źródeł odnawialnych koncentrują się na wykorzystaniu energii słonecznej, wiatrowej, wodnej, geotermalnej i różnego rodzaju biopaliw. 
The easiest to acquire is solar radiation, which is widely used in nature. The described examples of the use of radiation are passive methods, which are spontaneous and require no additional energy.

\section{PASSIVE TECHNOLOGIES OF ENERGY SAVINGS}

Passive cooling methods are a very broad group of different types of means, building techniques, architectural techniques as well as methods of decorating buildings that influence thermal comfort. They include a whole spectrum of different techniques such as:

- green facades,

- cooling coatings,

- thermosiphon and heat pipes,

- thermochromic paints,

- heater screens,

- blinds, awnings, etc.

One of the ideas for changing the thermal state of buildings is the use of coatings with the desired emission characteristics of external building baffles. The simplest solution is to use a color paint which, depending on the desired effect, can have a different absorption coefficient. Generally, it is possible to choose dark colors for radiative heat gains, and for light colors to be limited. In the example of three buildings in Shanghai, it has been found that the use of special reflective coatings can reduce the surface temperature of the southern wall, depending on the coating, from $4.6^{\circ} \mathrm{C}$ to as much as $20^{\circ} \mathrm{C}$. Three coverings were tested: one for basic and two for comparison, with selective responses to falling sunlight. Also tested are specially prepared acrylic paints with different emissivity and absorption properties. The literature results show that it is possible to lower the surface temperature by more than $10^{\circ} \mathrm{C}[3]$.

Thermopaints for facades and roofs are also available. Their chemical composition and manufacturing technology is protected and only general information is available in the literature. It is known, for example, that one of the components used is titanium dioxide. In the study [4] eleven aluminum samples painted with various titanium dioxide thermochromatic paints were tested and compared with samples painted without additives. The results show that thermochromic paints effectively improve reflective properties by increasing the reflection of sunlight by as much as $43 \%$.
Najłatwiejszym do pozyskiwania jest promieniowanie słoneczne, którego wykorzystanie jest szeroko spotykane w przyrodzie. Opisane przykłady wykorzystania promieniowania należą do metod pasywnych, a więc takich, które zachodzą samorzutnie i nie wymagają dodatkowej energii.

\section{METODY PASYWNE}

Pasywne metody chłodzenia to bardzo szeroka grupa różnego rodzaju środków, technik budowlanych, architektonicznych, jak i metod wystroju budynków wpływająca na komfort cieplny. Zalicza się do nich całe spektrum różnorakich technik, takich jak:

- zielone fasady,

- powłoki chłodzące,

- termosyfony i rurki cieplne,

- farby termochromowe,

- ekrany zagrzejnikowe,

- żaluzje, markizy itp.

Jednym ze sposobów na zmianę stanu termicznego budynków jest zastosowanie pokryć o pożądanych właściwościach emisyjnych zewnętrznych przegród budowlanych. Najprostszym rozwiązaniem jest użycie kolorowej farby, która w zależności od pożądanego efektu może charakteryzować się różnym współczynnikiem absorpcji. Można przyjąć, że aby zwiększyć radiacyjne zyski ciepła, należy wybierać kolory ciemne, a dla ich ograniczenia kolory jasne. Na przykładzie trzech budynków w Szanghaju [2] stwierdzono, że zastosowanie specjalnych powłok refleksyjnych może przyczynić się do zmniejszenia temperatury powierzchni zewnętrznej ściany południowej, w zależności od pokrycia, od $4,6^{\circ} \mathrm{C}$ do nawet $20^{\circ} \mathrm{C}$. Badano tam trzy pokrycia: jedno podstawowe i dla porównania dwa o cechach selektywnej reakcji na padające promieniowanie słoneczne. Prowadzone są badania specjalnie spreparowanych farb akrylowych o różnych właściwościach emisyjno-absorpcyjnych. Podawane w literaturze wyniki badań wskazują, że możliwe jest obniżenie temperatury powierzchni o ponad $10^{\circ} \mathrm{C}[3]$.

Na rynku dostępne są termofarby do elewacji i dachów. Ich skład chemiczny i technologia wytwarzania są chronione i tylko ogólne informacje są dostępne. Wiadomo na przykład, że jednym z wykorzystywanych składników jest dwutlenek tytanu. W pracy [4] przeprowadzono badania na 11 próbkach aluminiowych pomalowanych różnymi farbami termochromatycznymi z dodatkiem dwutlenku tytanu i dla porównania z próbkami pomalowanymi farbą bez dodatków. Wyniki wykazały, że farby termochromatyczne poprawiają właściwości refleksyjne, zwiększając odbicie promieniowania słonecznego nawet o $43 \%$. 


\subsection{Green facades}

One of the oldest methods is to limit the penetration of sunlight by planting different types of plants to produce a leaf layer that absorbs sunlight. Plants used for this purpose are various types of vines, and in particular various varieties of vines, hops or bulrushes. This method is very old - used in construction for several thousand years. Until today, it is used in countries with high levels of irradiation. The use of such green covers can reduce the surface temperature by up to $4^{\circ} \mathrm{C}[5]$.

According to research conducted in Singapore, the demand for cooling after application of the plant layer has decreased by $10 \%$ [7]. An experiment in Beijing has shown that thick ivy covering the western wall can reduce peak demand for cooling by $28 \%$ on a sunny summer day [8]. It is assumed that the thermal resistance of the plant layer is small and is about 0.7 $\mathrm{m}^{2} / \mathrm{KW}$. Figures 1 and 2 show an example of a green facade.

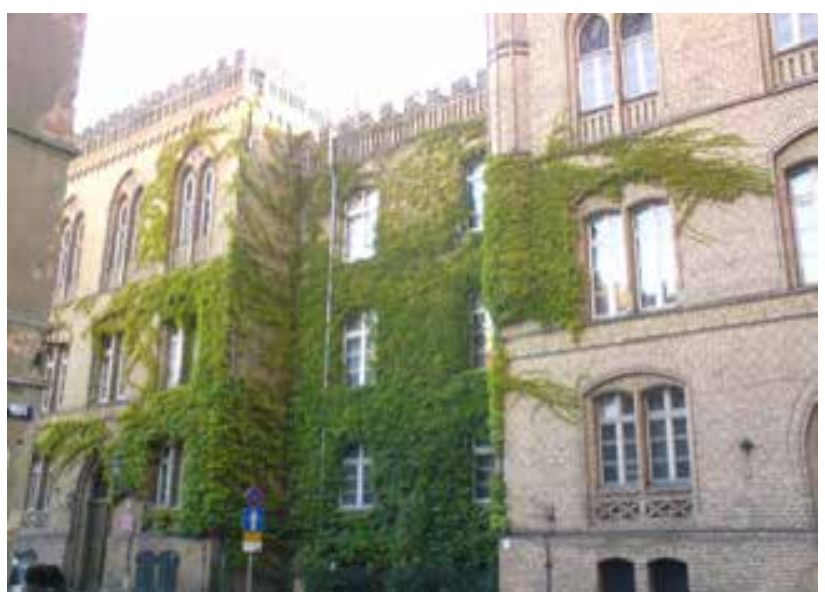

Fig. 1. Building of district Court in Torun [15]

Rys. 1. Budynek Sadu Okręgowego w Toruniu [15]

\subsection{Cool coatings}

One of the variants of broadly understood passive technologies are so-called cool coatings. The following types of coatings are distinguished:

- cooling roofs and facade coverings,

- cooling coatings (paint),

- waterproof membrane,

- cooling plates,

- natural cooling materials.

\subsection{Zielone fasady}

Jedną z najstarszych metod jest ograniczenie przenikania promieniowania słonecznego przez nasadzanie różnego rodzaju roślin mających wytworzyć warstwę liści, która absorbuje promieniowanie słoneczne. Roślinami wykorzystywanymi do tego celu są najróżniejsze rodzaje pnączy, a w szczególności różne odmiany winorośli, chmielu czy powojów. Metoda ta jest stosowana w budownictwie od kilku tysięcy lat. Do dnia dzisiejszego jest wykorzystywana w krajach o występującym wysokim napromieniowaniu. Użycie zielonych osłon może obniżać temperaturę powierzchni nawet o $4^{\circ} \mathrm{C}$ [5].

Według badań prowadzonych w Singapurze zapotrzebowanie na chłód po zastosowaniu warstwy roślinnej zmalało o 10\% [7]. Eksperyment przeprowadzony w Pekinie wykazał, że gruby bluszcz pokrywający zachodnią ścianą, może zmniejszyć szczytowe zapotrzebowanie na chłodzenie o $28 \% \mathrm{w}$ słoneczny letni dzień [8]. Przyjmuje się, że opór cieplny warstwy roślinnej jest niewielki i wynosi około $0,7 \mathrm{~m}^{2} / \mathrm{KW}$. Na rysunkach 1 i 2 pokazano przykładową przegrodę $\mathrm{z}$ zieloną fasadą.

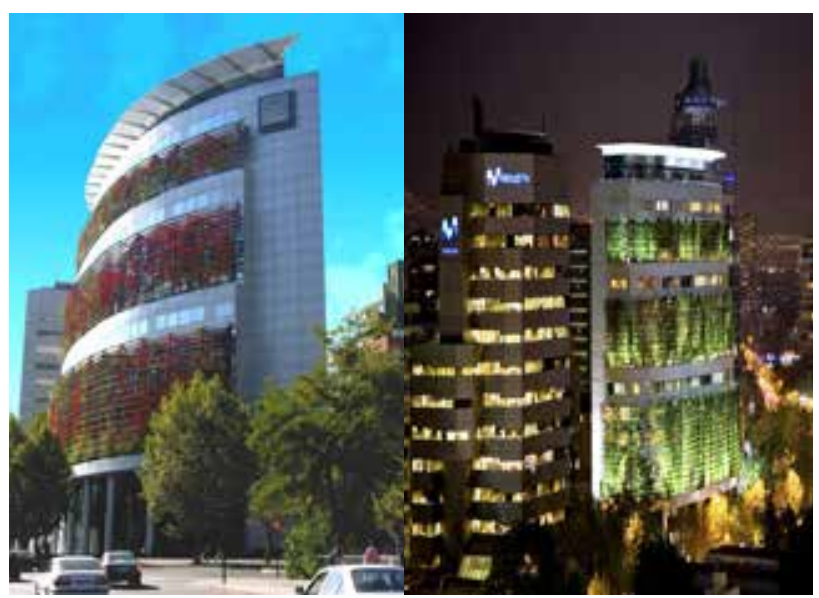

Fig. 2. Consorcio Santiago Building in Santiago de Chile during day and night [14]

Rys. 2. Consorcio Santiago Building w Santiago de Chile $w$ dzień oraz $w$ nocy [14]

\subsection{Powłoki chłodzące}

Jednym z wariantów szeroko pojętych technologii pasywnych są tak zwane powłoki chłodzące. Wyróżnia się następujące rodzaje tych powłok:

- chłodzące dachy i pokrycia fasad,

- chłodzące pokrycia (farby),

- wodoodporne membrany,

- płytki chłodzące,

- naturalne materiały chłodzące. 
Cooling roofs are usually covered with various types of membranes, gravel, paint or metal plates. Typically, cooling roofs are a one-layered structure. Typical liquid used for cooling coatings consists of white paint, polyurethane, elastomeric or acrylic coatings and can also be made of other plastics such as EPDM, PVC or CPE. It was found that the black roof covered with asphalt after applying the cooling coating changed its reflectivity coefficient from 0.04 to 0.8 [9]. The material that heats up to $75-80^{\circ} \mathrm{C}$ after using of cool coating heating is heated to $45^{\circ} \mathrm{C}$.

These elements use selective absorption and emission of solar radiation. Their use in building construction reduces the building's cooling load, improves the thermal comfort of the building, increases the roof's resistance due to the reduction of stress caused by the temperature. Such coating properties result in increased reflectivity and lower absorption. Therefore, such coatings are a good way to weaken the effect of the City Heat Island.

Crafted surfaces are characterized by a reflection coefficient greater than $80 \%$ and a high emissivity of about 0.8-0.9 [9]. Both of these values are used to calculate the Solar Reflectance Index (SRI).

Cooling paints are the most common and effective way of shaping the outside temperature of a building. They also have better cooling properties compared to materials such as white marble or white mosaics. Most of these paints are based on zinc dioxide or titanium dioxide, whose reflectivity is in the range of $0.7-0.85$. The use of this type of coating allows the absorption coefficient to be reduced to about 0.2. A similar effect can be achieved by the addition of suitable pigments, which improve the reflective properties of the coating, especially in the field of infrared radiation. In the literature it is stated that the difference in surface temperature between the painted black reflective paint and the ordinary black paint reaches more than $10^{\circ} \mathrm{C}[9,11]$. Figure 3 shows an example application of this technology.

Instead of painting, waterproof membranes made of plastics are used. Zinc dioxide and ceramics are added to them. Their standard reflectivity is about 0.81-0.84. Standardized coatings can improve energy efficiency, which is understood to reduce energy consumption by up to $19.3 \%$ [9].

Coatings can also be covered with ceramic tiles, made of silicate gel, combined with thin aluminum foil with low emissivity (Fig. 4). This plate design allows for increased resistance to thermal conditions, and additionally allows control of heat loss in winter and summer gains. The reflectance in literature is about 0.75 . This results in a cooling cost reduction of over $50 \%$ [9]. Their performance
Dachy chłodzące są zazwyczaj pokrywane różnego rodzaju membranami, żwirami, farbami lub metalowymi płytkami. Zazwyczaj dachy chłodzące są strukturą jednowarstwową. Typowy płyn używany do chłodzących powłok składa się z białej farby, poliuretanowych, elastomerowych lub akrylowych powłok, a także może być wykonany $\mathrm{z}$ innych tworzyw sztucznych, jak EPDM, PVC czy CPE. Stwierdzono, że czarny dach pokryty asfaltem, po nałożeniu powłoki chłodzącej, zmienił swój współczynnik refleksyjności z 0,04 do 0,8 [9]. Materiał nagrzewający się do temperatury $75-80^{\circ} \mathrm{C}$, po zastosowaniu powłoki, nagrzewa się do temperatury $45^{\circ} \mathrm{C}$.

Elementy te wykorzystują zjawiska selektywnej absorpcji i emisji padającego na nie promieniowania słonecznego. Ich zastosowanie w budownictwie na elementach budynków pozwala na zmniejszenie obciążenia chłodniczego budynku, poprawienie komfortu cieplnego we wnętrzu obiektu oraz zwiększenie odporności dachu na skutek zmniejszenia naprężeń wywołanych temperaturą. Takie właściwości powłok skutkują zwiększoną refleksyjnością i niższą absorpcją. Z tego względu takie powłoki są dobrym sposobem do osłabienia efektu miejskiej wyspy ciepła.

Opisane w literaturze najkorzystniej spreparowane powierzchnie charakteryzują się współczynnikiem odbicia powyżej $80 \%$ i wysoką emisyjnością wynoszącą około 0,8-0,9 [9]. Obie te wartości są wykorzystywane do obliczenia zastępczego współczynnika emisji (Solar Reflectance Index - SRI).

Farby chłodzące są najbardziej rozpowszechnionym i skutecznym sposobem kształtowania temperatury zewnętrznej budynku. Mają też korzystniejsze własności chłodzące w porównaniu do takich materiałów jak biały marmur czy białe mozaiki. W większości skład takich farb jest oparty na bazie dwutlenku cynku lub tytanu, którego współczynnik odbicia zawiera się $\mathrm{w}$ przedziale $0,7-0,85$. Stosowanie tego rodzaju pokryć umożliwia ograniczenie współczynnika absorpcji do wartości około 0,2. Podobny efekt można osiągnąc przez dodanie odpowiednich pigmentów, których zadaniem jest poprawa właściwości refleksyjnych pokrycia, szczególnie w zakresie promieniowania podczerwonego. $\mathrm{W}$ literaturze podaje się, że różnica $\mathrm{w}$ temperaturze powierzchni między pomalowaną czarną farbą refleksyjną a farbą czarną zwykłą dochodzi do ponad $10^{\circ} \mathrm{C}[9,11]$. Na rysunku 3 pokazano przykładową aplikację tej technologii.

Zamiast malowania stosuje się zabarwienia wodoszczelnych membran wykonywanych z tworzyw sztucznych. Dodaje się do nich cząsteczki dwutlen- 


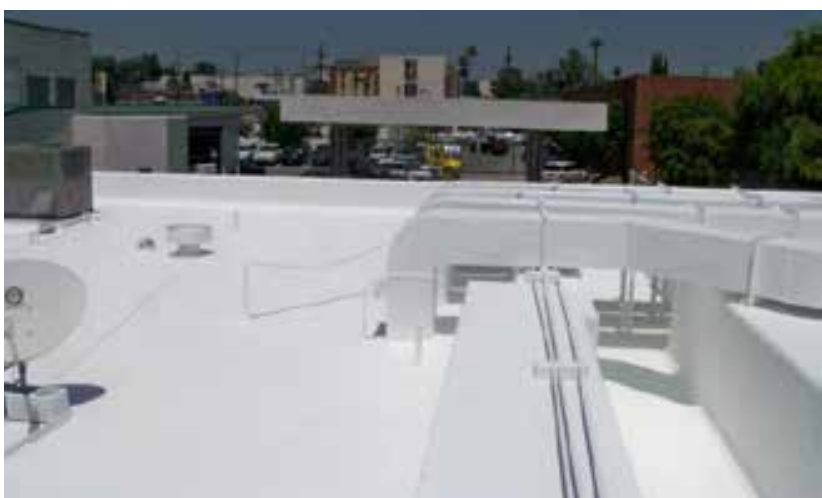

Fig. 3. Roof painted with cool paint [17]

Rys. 3. Dach pokryty biata farba chtodzaca [17]

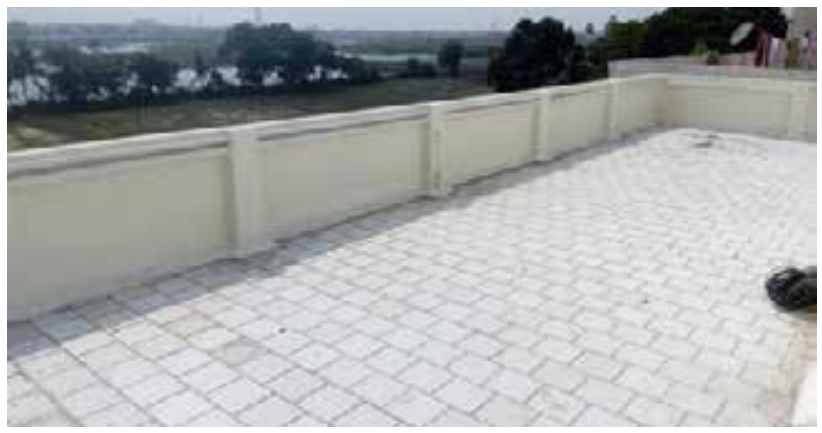

Fig. 4. Roof with mounted cool tiles [17]

Rys. 4. Dach z zamontowanymi phytkami chłodzacymi [17]

in the form of a traditional tile keeps the aesthetic qualities of the roof. A similar effect is obtained by spraying a latex lacquer onto the concrete surface.

In countries with high sunshine, such as in the Mediterranean, gravel, light marble and light stones are used. These materials are characterized by relatively high reflectivity ratios (for example, about $79 \%$ for marble [9]). In addition, such natural cooling materials have low cost of acquisition, production and assembly.

The use of these solutions in new and existing buildings contributes to the energy efficiency of buildings in times of excessive heat. In work [9] it is stated that energy savings are in the range of $2-44 \%$, their average value is $20 \%$. These values depend on local climate, sky conditions and ventilation and air conditioning systems. US research shows that cooling energy gains are $12-25 \%$ for single family housing, $5-18 \%$ for office buildings and $7-17 \%$ for utility buildings. Estimates show that for the 50-year cooling roof, the profits generated by the construction are approximately $\$ 25$ per square meter compared to the black roof (ie, covered with tarpaulin, etc.).

\subsection{Heater screen}

Various heater surfaces are of particular importance in passive technologies. For example, increasing the ku cynku i ceramiki. Ich standardowa refleksyjność promieniowania wynosi około 0,81-0,84. Standardowo dostępne powłoki mogą zwiększyć efektywność energetyczną, rozumianą jako zmniejszenie zużycia energii na chłodzenie nawet o ponad 19,3\% [9].

Powłokami takimi mogą być również powierzchnie pokryte płytkami ceramicznymi, wykonanymi z silikatowego żelu połączonego z cienką folią aluminiową o niewielkiej emisyjności (rys. 4). Taka konstrukcja płytki umożliwia podwyższenie odporności na warunki termiczne, a dodatkowo umożliwia kontrolę strat ciepła zimą i zysków latem. Podawany w literaturze współczynnik odbicia wynosi około 0,75 . Prowadzi to do obniżenia kosztów chłodzenia o ponad 50\% [9]. Ich wykonanie w formie tradycyjnej dachówki utrzymuje walory estetyczne dachu. Podobny efekt uzyskuje się przez natrysk lakierem lateksowym na powierzchnię betonu.

W krajach o dużym nasłonecznieniu, np. w basenie Morza Śródziemnego, stosuje się żwir, jasny marmur $\mathrm{i}$ jasne kamienie. Materiały te w stosunku do innych charakteryzują się stosunkowo wysokimi współczynnikami odbicia (np. dla marmuru jest to około $79 \%$ [9]). Dodatkowo takie naturalne materiały, chłodząc, mają niskie koszty pozyskania, produkcji i montażu.

Stosowanie tego rodzaju rozwiązań w nowych i istniejących budynkach przyczynia się do poprawy efektywności energetycznej obiektów w okresie nadmiernych temperatur. W pracy [9] podano, że oszczędności energii zawierają się $\mathrm{w}$ przedziale $2-44 \%$, a ich przeciętna wartość wynosi $20 \%$. Wartości te są zależne od lokalnego klimatu, stanu nieba, jak i systemów wentylacyjno-klimatyzacyjnych. Prowadzone w Stanach Zjednoczonych badania dowodzą, że zyski energii chłodzenia wynoszą 12-25\% dla budownictwa jednorodzinnego, 5-18\% dla budynków biurowych i 7-17\% dla budynków użytkowych. Szacunkowe obliczenia wskazują, że dla 50-letniego okresu pracy dachu chłodzącego zyski generowane przez konstrukcję wynoszą około $25 \$$ dla metra kwadratowego, w porównaniu do dachu czarnego (np. pokrytego papą itp.).

\subsection{Wykładziny zagrzejnikowe}

Szczególną rolę w technologiach pasywnych pełnią różnorakie wykładziny zagrzejnikowe. Na przykład zwiększenie chropowatości powierzchni przez zastosowanie faktury ząbków piły i materiałów o wysokiej emisyjności powoduje wyższą burzliwość przepływu powietrza, a tym samym wzrost wymiany ciepła nawet o $26 \%$ [6]. Dodatkowo ilość ciepła przenikające- 
surface roughness by using a saw tooth texture and high emissivity materials results in a higher airflow turbulence, which results in an increase in heat exchange by up to $26 \%$ [6]. In addition, the amount of heat penetrating the outer baffle decreases by $54 \%$. The result is an increased heat output of the heater by approximately $12 \%$. This is especially recommended for uninsulated or poorly insulated compartments.

\subsection{Blinds}

The bulk of the heat gains or losses in the building have transparent bulkheads. One way to limit these phenomena is to use different types of shutters, awnings and shutters. Such elements are made as internal or external, sometimes with varying vertical or horizontal inclination. In the literature it is stated that when in the warmest and strongest sunshine periods, when the surface of the absorbing baffle is facing outward, the temperature can be reduced by about $1 \mathrm{~K}$ at the facade at a distance of about $0.5 \mathrm{~m}$ [10]. This result was obtained using appropriately directed aluminum overlays.

\subsection{Thermosiphonges and heat pipes}

One of the most interesting solutions is the systems based on heat pipes or thermosiphas which are used for, among others, heat transfer, temperature stabilization and density regulation of heat flux. In construction and environmental engineering, in solar collectors, heat exchangers, wall heating and radiation wall panels [12].

Heat pipes can be divided by the way the condensate is transported to the evaporator. There are thermosiphates, rotating heat pipes and capillary tubes, where the condensate transport occurs as a result of the capillary pressure.

In transport and construction, for the sake of cost, the use of thermosiphon was mainly used. Where heat transport is to be independent of the direction of gravity, heat pipes are used. They are applied to:

- ground stabilization around foundations and supports in arctic areas,

- defrosting icy roads,

- preparation of hot water in heat exchangers,

- accumulation of solar energy in solar collectors,

- wall and floor heating,

- ventilation of air in combination with ecological energy sources [13].

An example of the use of heat pipes is the stabilization of the soil that was carried out during the construction of the railway line between China and Tibet. They are located in sections where there go przez przegrodę zewnętrzną maleje o 54\%. Wynikiem takiego zabiegu jest zwiększona wydajność cieplna grzejnika o około $12 \%$. Takie rozwiązanie jest szczególnie polecane przy nieizolowanych lub słabo izolowanych przegrodach.

\section{4. Żaluzje}

Największy wpływ na zyski lub straty ciepła w budynku mają przegrody przezroczyste. Jedną z metod ograniczenia tych zjawisk jest stosowanie różnego rodzaju żaluzji, markiz i rolet. Elementy takie są wykonywane jako wewnętrzne lub zewnętrzne, czasami o zmiennym kącie pochylenia w pionie lub poziomie. W literaturze podaje się, że gdy w okresach najcieplejszych i przy silnej operacji promieniowania słonecznego, kiedy powierzchnia przegrody absorbującej jest skierowana na zewnątrz, temperatura może zostać zredukowana o około $1 \mathrm{~K}$ przy fasadzie w odległości około $0,5 \mathrm{~m}$ [10]. Wynik ten uzyskano przy zastosowaniu odpowiednio skierowanych nakładek aluminiowych.

\subsection{Termosyfony i rurki cieplne}

Jednym z ciekawszych rozwiązań są układy pracujące w oparciu o rurki cieplne lub termosyfony, które stosowane są między innymi do transportu ciepła, stabilizacji temperatur oraz regulacji gęstości strumienia ciepła. W budownictwie i inżynierii środowiska znalazły swoje zastosowanie m.in. w kolektorach słonecznych, wymiennikach ciepła, systemach ogrzewania ściennego i radiacyjnych panelach ściennych [12].

Rurki cieplne można podzielić ze względu na sposób transportu skroplin do parownika. Wyróżnia się tu termosyfony, wirujące rury cieplne oraz rury ze strukturami kapilarnymi, gdzie transport kondensatu następuje w wyniku działania ciśnienia kapilarnego.

W transporcie i budownictwie, ze względu na koszty, zastosowanie znalazły przede wszystkim termosyfony. W przypadkach kiedy transport nośnika ciepła ma być niezależny od kierunku grawitacji, stosuje się rurki ciepła. Wykorzystywane są one do:

- stabilizacji temperatury gruntu wokół fundamentów i podpór w obszarach arktycznych,

- rozmrażania oblodzonych dróg,

- przygotowania ciepłej wody użytkowej w wymiennikach ciepła,

- akumulacji energii słonecznej w kolektorach słonecznych,

- ogrzewania ściennego i podłogowego,

- podgrzewania powietrza wentylacyjnego $\mathrm{w}$ połączeniu z ekologicznymi źródłami energii [13]. 
is eternal permafrost. During the thaw, the ground under the railway sleepers was thawing, which caused the tracks to collapse or even break the rails. The condensation section of the tube has been ribbed and extended over the surface of the ground, where it draws heat from the ground to the air. This has led to a decrease in the temperature of the soil which, even during the thaw, has a negative temperature, which excludes the possibility of catastrophe [18]. Similar solutions were used in the construction of a pipeline that transported oil north to south of Alaska [19]. A number of heat pipes have been installed along the route of this pipeline, which protects the ground from drenching and the pipeline from damage. In Scandinavia, heat pipes are used to heat the road. They are installed directly below the road surface to maintain a constant, positive asphalt temperature [18]. Similar solutions are used to heat surfaces of bridges and viaducts. In such cases they may be passive or active systems [12].

\section{FINDINGS}

Painting exterior facade of the building with the same pigmented pigment of different colors results in different radiative gains, which directly translates into winter and cooling summer heat load. Further research is needed to determine the optimum building colors and thermochromic colors.

Based on the proposed methodology discussed in [1] and [11], the absorption and emission coefficients for the four samples were determined. Three of them were covered with a paint of this composition, but dyed with different dye, the fourth with a $99.9 \%$ purity. The results are shown in Table 1.
Przykładem zastosowania rurek ciepła jest stabilizacja gruntu, którą przeprowadzono przy budowie linii kolejowej między Chinami a Tybetem. Umieszczono je na odcinkach, gdzie występuje wieczna zmarzlina. W czasie odwilży grunt pod podkładami kolejowymi ulegał rozmrożeniu, co było powodem zapadania się konstrukcji torów, a nawet łamania szyn. Sekcja skraplająca rurek została ożebrowana i wysunięta nad powierzchnię gruntu, gdzie oddaje pobrane z ziemi ciepło do powietrza. Spowodowało to obniżenie temperatury gruntu, który nawet podczas odwilży ma ujemną temperaturę, co wykluczyło możliwość występowania katastrof [18]. Podobne rozwiązania były wykorzystywane przy budowie rurociągu, którym transportowana jest ropa naftowa z północy na południe Alaski [19]. Wzdłuż trasy tego rurociągu zainstalowano szereg rurek ciepła, które zabezpieczają grunt przed rozmarzaniem, a rurociąg przed uszkodzeniem. W krajach skandynawskich rurki ciepła służą do ogrzewania jezdni. Instaluje się je bezpośrednio pod powierzchnią drogi, aby utrzymywały stałą, dodatnią temperaturę asfaltu [18]. Podobne rozwiązania wykorzystuje się do podgrzewania powierzchni mostów i wiaduktów. W takich przypadkach mogą być to systemy w układzie pasywnym lub aktywnym [12].

\section{WYNIKI BADAŃ}

Malowanie elewacji zewnętrznej budynku tą samą farbą, zabarwioną pigmentem o różnym kolorze, powoduje różne zyski radiacyjne, co bezpośrednio przekłada się na obciążenie cieplne zimą i chłodnicze latem. Dlatego istnieje potrzeba przeprowadzenia dalszych badań w celu wyznaczenia optymalnych barw budowlanych oraz kolorów termochromowych.

W oparciu o zaproponowaną metodykę omówioną w pracy [1] i [11] wyznaczono współczynniki absorpcji i emisji dla czterech próbek. Trzy z nich pokryto farbą o tym samym składzie, lecz zabarwionych różnym barwnikiem, czwartą zaś proszkiem węglowym o czystości 99,9\%. Wyniki badań przedstawiono w tabeli 1.

Table 1. Summary of absorption and emission factors

Tabela 1. Zestawienie wspótczynników absorpcji i emisji

\begin{tabular}{|c|c|c|c|c|}
\hline Colour of surface & \multicolumn{3}{|c|}{ Coefficient of emission $\varepsilon$} & \multirow{2}{*}{ Coefficient of absorption $a$} \\
\hline White & heating & cooling & average value & 0.51 \\
\hline Light blue & 0.765 & 0.755 & 0.760 & 0.74 \\
\hline Green & 0.861 & 0.859 & 0.860 & 0.73 \\
\hline Coal & 0.89 & 0.887 & 0.888 & 0.95 \\
\hline
\end{tabular}


Using the values in Table 1, the radiation gains for the sample barrier of the analyzed building were calculated. It was assumed that the object is located in Kielce, where detailed meteorological data are needed to estimate daily heat gains. It was assumed that the room was $3.7 \mathrm{~m}$ long, $3.4 \mathrm{~m}$ wide and 3.2 $\mathrm{m}$ high. Its ceiling is covered with tarpaulin and the heat transfer coefficient for the ceiling is $0.248 \mathrm{~W} /$ $\mathrm{m}^{2} \mathrm{~K}$ and for the wall is $0.350 \mathrm{~W} / \mathrm{m}^{2} \mathrm{~K}$ respectively. Sample cooling load calculations were carried out for the non-transparent partitions to the south for the month of June. Using the measured values of the coefficients according to Table 1, the maximum daily load of the partition was calculated, which for white is $57.11 \mathrm{~W} / \mathrm{m}^{2}, 68.35 \mathrm{~W} / \mathrm{m}^{2}$, light blue $68.86 \mathrm{~W} / \mathrm{m}^{2}$, and black $79.6 \mathrm{~W} / \mathrm{m}^{2}$.

\section{CONLUSIONS}

Passive methods are an important method of reducing energy consumption in buildings. They are a relatively inexpensive way of building comfort in buildings relative to traditional air conditioning systems. Their appropriate application can significantly improve the performance of air conditioning systems in buildings. They are characterized by different characteristics. They also differ in the cost of the investment. It is assumed that traditional passive methods such as green facades and roofs are the cheapest and requiring the least work, the latest, most innovative and experimental methods are the most expensive. Selection of the most advantageous method requires careful economic analysis.

The effects of the use of cooling coatings are very broad and, depending on the type, lead to:

- energy savings,

- mitigating the effects of urban heat islands,

- building comfort inside the premises,

- improve the external environment,

- prolonged working time of roof elements,

- optimizing ventilation and air conditioning.

The results show that the emission and absorption properties of the baffles can be used to create the appropriate thermal comfort. During the winter season, high-emission coatings can be used, while in the low summer months. The ideal would be a coating that adapts its properties to the currently prevailing thermal conditions, which requires further research, which is carried out in many scientific means.
Korzystając z wartości zamieszczonych w tabeli 1, obliczono zyski radiacyjne dla przykładowej przegrody analizowanego budynku. Przyjęto, że obiekt jest położony w Kielcach, gdzie dostępne są szczegółowe dane meteorologiczne, niezbędne do oszacowania dobowych zysków ciepła. Przyjęto również, że pomieszczenie ma 3,7 m długości, 3,4 m szerokości oraz 3,2 m wysokości. Jego stropodach jest pokryty papą, a współczynnik przenikania ciepła dla stropu wynosi $0,248 \mathrm{~W} / \mathrm{m}^{2} \mathrm{~K}$, natomiast dla ściany $0,350 \mathrm{~W} / \mathrm{m}^{2} \mathrm{~K}$. Przykładowe obliczenia obciążenia chłodniczego przeprowadzono dla przegrody nieprzezroczystej skierowanej na południe, dla miesiąca czerwca. Wykorzystując zmierzone wartości współczynników według tabeli 1, obliczono maksymalne dzienne obciążenie przegrody, które dla koloru białego wynosi $57,11 \mathrm{~W} / \mathrm{m}^{2}$, dla zielonego $68,35 \mathrm{~W} / \mathrm{m}^{2}$, jasnoniebieskiego $68,86 \mathrm{~W} / \mathrm{m}^{2}$, a dla czarnego $79,6 \mathrm{~W} / \mathrm{m}^{2}$.

\section{WNIOSKI}

Metody pasywne stanowią ważną metodę ograniczania zużycia energii w budynkach. Stanowią one relatywnie tanią w stosunku do tradycyjnych systemów klimatyzacyjnych metodę kształtowania komfortu cieplnego w budynkach. Ich odpowiednie zastosowanie może wydatnie zwiększyć wydajność systemów klimatyzacji w obiektach. Charakteryzują się różnymi cechami. Różnią się także kosztami inwestycji. Przyjmuje się, że tradycyjne metody pasywne, jak zielone fasady i dachy, są najtańsze i wymagają najmniejszego wkładu pracy, metody najnowsze, najbardziej innowacyjne i eksperymentalne są najdroższe. Wybór najkorzystniejszej metody wymaga dokładnej analizy ekonomicznej.

Efekty, jakie daje stosowanie powłok chłodzących, są bardzo szerokie i w zależności od typu prowadzą do:

- oszczędności energii,

- łagodzenia efektów miejskich wysp ciepła,

- budowy komfortu cieplnego wewnątrz pomieszczeń,

- poprawy warunków zewnętrznych,

- wydłużenia czasu pracy elementów dachowych,

- optymalizacji pracy urządzeń wentylacyjnych i klimatyzacyjnych.

Z przeprowadzonych badań wynika, że właściwości emisyjne i absorpcyjne przegród mogą zostać użyte do odpowiedniego kształtowania komfortu cieplnego. W okresie zimowym można używać powłoki o wysokim współczynniku emisji, zaś latem o niskim. Ideałem byłaby powłoka dostosowująca swe właściwości do aktualnie panujących warunków termicznych, co wymaga dalszych badań, które są prowadzone w wielu ośrodkach naukowych. 


\section{References}

[1] Bergman T.L., Lavine A.S., Incropera F.P., Devitt D.P., Fundamentals of heat and mass transfer, Wiley 2011.

[2] Shen H., Tan H., Tzempelikos A., The effect of reflective coatings on building surface temperatures, indoor environment and energy consumption - An experimental study. Energy and Buildings, 43 (2011), pp. 573-580.

[3] Uemoto K.L., Sato N.M.N., Vanderley M.J., Estimating thermal performance of cool colored paints. Energy and Buildings, 42 (2010), pp. 17-22.

[4] Karlessi T., Santamouris M., Apostolakis K., Synnefa A., Livada I., Development and testing of thermochromic coatings for buildings and urban structures. Solar Energy, 83 (2009), pp. 538-551.

[5] MacIvor J.S., Margolis L., Cooling of a South-Facing Wall Using a Double-Skin Green Façade in a Temperate Climate.

[6] Shati A.K.A., Blakey S.G., Beck S.B.M., The effect of surface roughness and emissivity on radiator output. Energy and Buildings, 43 (2011), pp. 400-406.

[7] Wong N.H., Kwang Tan A.Y., Chen Y., Sekar K., Tan P.Y., Chan D., Wong, N.C. (2010), Thermal evaluation of vertical greenery systems for building walls. Building and Environ. 45:663-672.

[8] Di H.F., Wang D.N. (1999), Cooling effect of ivy on a wall. Experimental Heat Transfer 12:235-245.

[9] Pisello L., State of the art on the development of cool coatings for buildings and cities. Solar Energy 144 (2017), pp. 660-680.

[10] Frontinia F., Kuhnb T.E., The influence of various internal blinds on thermal comfort: A new method for calculating the mean radiant temperature in office spaces. Energy and Buildings, 54 (2012), pp. 527-533.

[11] Orzechowski T., Lesiak P., Wptyw koloru elewacji budynku na zużycie energii. The influence of color on the facade of the building energy consumption, Współczesne problem termodynamiki, Gliwice 2017, s. 368-378.

[12] Tyburczyk A., Zjawiska zmiany fazy w pasywnym odszranianiu fragmentów dróg, Logistyka, nr 4/2015, ISSN 12315478, s. 6313-6319.

[13] Wiśniewski T.S., Wymiana ciepła, wydanie III, WNT, Warszawa 1995.

[14] Welch A., Consorcio Santiago: Chile Offices Building. https://www.e-architect.co.uk/chile/consorcio-santiagobuilding. Data dostępu 16.07.2017.

[15] http://www.garnek.pl/masytor/2588185/sad-okregowy-w-toruniu. Data dostępu 16.07.2017.

[16] Strona internetowa firmy Perfect - Contracting \& fire systems. http://perfectcfs.com/services/cool-roof/. Data dostępu 16.07.2017.

[17] Strona internetowa firmy Indianmart, https://www.indiamart.com/proddetail/cool-roof-tiles-11502802130.html. Data dostępu 16.07.2017.

[18] http://en.sunpower.com.cn/ Data dostępu 2.09.2017.

[19] http://www.alyeska-pipeline.com/ Data dostępu 2.09.2017.

\section{Acknowledgments:}

This work was supported by Kielce University of Technology, Grant No. 05.0.07.00/2.01.01.0015 MNSP.IKSI.14.001

\section{Podziękowania:}

Praca była finansowana przez Politechnikę Świętokrzyska, grant nr 05.0.07.00/2.01.01.0015 MNSP.IKSI.14.001 